\title{
Abstracts of Articles
}

"Some Problems of Brunei Chronology" by Robert Nicholl

Owing to the absence of dates in historical manuscripts and on monuments, Brunei chronology has been based upon traditional dates of uncertain origin. The object of this article is to take such events in Brunei as can be chronicled in external sources and to compare these foreign dates with those traditionally accepted.

"The Role of Governor D.J. Jardine in Improving the Welfare of the Indigenous People of Sabah, 1934-37" by Sabihah Osman

Douglas J. Jardine was Governor of British North Borneo (Sabah) from August 1934 to May 1937. Despite his short period in office, Jardine succeeded in bringing about considerable improvement in the country. The most important feature of his administration was his personal interest in the welfare of the native population, particularly with regard to their administration, education and health.

"Malayan Union Citizenship: Constitutional Change and Controversy in Malaya, 194248" by Albert Lau

Responding to the new forces unleashed by the Second World War, Whitehall planners devised a new scheme that envisaged the creation of Malayan Union Citizenship. In a fundamental break from past practice, the new scheme sought to confer citizenship privileges on Malaya's non-Malay population. In the aftermath of the War the implementation of the new policy embroiled the Colonial Office in a major constitutional controversy that threatened not only Britain's traditional relationship with the indigenous Malay community but also the bases of British rule in Malaya.

"Japan's Economic Expansion in the Netherlands Indies Between the First and Second World Wars" by Howard Dick

Japan's economic expansion into Southeast Asia which began during World War I laid the foundations for the contemporary regional order. Based mainly upon Dutch sources, this article reviews the interwar expansion of Japanese trade, shipping and investment in Indonesia, examines its corporate structure, and considers how the phenomenon should be interpreted.

"Self, Family and the State: Social Mythology in the Singapore Novel in English" by Koh Tai Ann

Adopting an approach that situates texts in their historical, political and cultural contexts, this discussion suggests that a strictly literary estimate of Singapore novels in English is an unrewarding, debunking exercise which prevents a more appropriately serious consideration of the insights that can yield about class, contemporary values, issues and society in Singapore.

"The Notion of 'Dakwah' and Its Perceptions in Malaysia's Islamic Literature of the 1970 s and '80s" by Ungku Maimunah Mohd. Tahir

Consistent with the call of the times to "return" to Islam, Malaysia's Sastera Islam of the 1970s and '80s upholds literature as a legitimate tool for "dakwah". Within this framework, production of Islamic literature demonstrates involvement of the "religious" sector and formalistic demands for Islamic moral underpinnings, the latter manifested largely in narrative concerns with individual morality and salvation. 